\title{
Pengaruh Pasta Gigi yang Mengandung Katekin Gambir (Uncaria gambir Roxb) terhadap Penurunan Indeks Plak Gigi
}

Nurhayati ${ }^{1}$, Bambang $\mathrm{R}^{1}$, Cimi Ilmiawati

Korespondensi : Nurhayati; adekinur91@gmail.com; Telp: 089503079765

\begin{abstract}
Background: Dental plaque is a soft, structured, calcified layer of bacteria that accumulates and attaches to the surface of the tooth. Efforts are made to eliminate and prevent plaque on the surface of the tooth by plaque control. Plaque control can be done mechanically, chemically, or a combination of both. Chemical control is done by using toothpaste. Catechin gambier toothpaste are polyphenolic compounds that have antibacterial activity which can prevent adhesion, inhibit the enzyme activity of glucosyltransferase and kills plaque forming bacteria. Objective: To determine the effect of catechin gambier on decreasing dental plaque index. Methods: This study is a true experimental study with pre-test and post-test control group design, conducted in March - April 2019. The subjects of this study were 44 students of Faculty of Dentistry, Andalas University. The subjects were divided into two groups, one group used catechin gambier toothpaste and an control group used placebo. Plaque index was calculated using an Turesky-Gilmore-Glickman of Quingley-Hein. Data was analyzed by $t$-test. Results: Average of dental plaque index in treatment group was higher than placebo group. Independent $t$-test showed that there was significant difference of dental plaque index beetwen two groups $(p<0,001)$. Conclusion: Catechin gambier toothpaste can reduce dental plaque index.
\end{abstract}

Keywords: Catechin; dental plaque; gambier; plaque index.

Affiliasi penulis : ${ }^{1}$ Fakultas Kedokteran Gigi, Universitas Andalas; ${ }^{2}$ Fakultas Kedokteran Universitas Andalas.

\section{PENDAHULUAN}

Kesehatan gigi dan mulut merupakan bagian dari kesehatan tubuh yang tidak dapat dipisahkan satu dan lainnya karena akan mempengaruhi kesehatan tubuh keseluruhan. Berdasarkan data Riset Kesehatan Dasar (Riskesdas) terdapat peningkatan persentase penduduk yang mempunyai masalah gigi dan mulut pada tahun 2007 dan 2013, yaitu dari 23,2\% menjadi 25,9\%. Angka ini menunjukkan bahwa jumlah penduduk yang tidak peduli dengan kesehatan gigi dan mulut di Indonesia semakin meningkat. Dari data penduduk yang mempunyai masalah gigi dan mulut, hanya $8,1 \%$ yang menerima perawatan atau pengobatan dari tenaga kesehatan gigi ${ }^{1,2}$. Masalah kesehatan gigi dan mulut yang sering dikeluhkan masyarakat Indonesia adalah karies dan penyakit periodontal ${ }^{3}$.

Salah satu upaya preventif dalam menurunkan angka penyakit periodontal adalah kontrol plak4. Kontrol plak merupakan suatu upaya pencegahan untuk menghilangkan plak gigi secara teratur yang dapat dilakukan dengan cara mekanis dan kimiawi serta kombinasi keduanya. Pembuangan secara mekanis merupakan metoda yang efektif dalam mengendalikan plak dan inflamasi gingiva, yang meliputi penyikatan gigi dan pembersihan interdental dengan benang gigi (flossing). Kontrol plak secara kimiawi dapat dilakukan dengan menggunakan pasta gigi dan larutan obat kumur. Penggunaan benang gigi (flossing) sering tidak memberikan hasil yang maksimal pada anak, sehingga menyebabkan 
terganggunya kesehatan gusi ${ }^{5}$. Oleh karena itu, bahan kimia seperti pasta gigi dapat dipergunakan sebagai sarana dalam menunjang pengendalian plak $^{6}$. Kontrol plak dilengkapi dengan penambahan jenis bahan aktif yang mengandung bahan dasar alami maupun bahan sintetik sebagai bahan antibakteri dalam pasta gigi ${ }^{7}$. Penggunaan pasta gigi yang mengandung bahan dasar alami berupa propolis, terbukti dapat menurunkan indeks plak gigis ${ }^{8}$

World Health Organization (WHO) menganjurkan pemanfaatan obat tradisional dalam rangka peningkatan dan pelayanan kesehatan ${ }^{9}$. Indonesia dikenal sebagai mega center keanekaragaman hayati (biodiversity) terbesar kedua di dunia. Indonesia memiliki 30.000 jenis tumbuhan dan 7.000 diantaranya memiliki khasiat sebagai obat ${ }^{10}$. Salah satu tumbuhan yang memiliki banyak manfaat dalam obatobatan tradisional adalah gambir ${ }^{11}$. Gambir merupakan tumbuhan asli Asia Tenggara, komoditas utama provinsi Sumatera Barat yang memasok $80 \%$ dari total gambir yang dihasilkan di Indonesia ${ }^{12}$. Ekstrak gambir mengandung katekin sebagai komponen utama, yaitu suatu senyawa polifenol yang berpotensi sebagai antioksidan dan antibakteri ${ }^{12}$. Gambir dikenal sebagai sumber katekin yang kandungannya melebihi dari tanaman lain seperti teh. Kadar katekin teh hijau berkisar 20-30\%, sedangkan kadar katekin pada gambir dapat mencapai 67,55-72,02\%, sehingga kadar katekin gambir lebih tinggi dari kadar katekin teh hijau ${ }^{14}$.

Penggunaan gambir sebagai sediaan pasta gigi merupakan salah satu usaha dalam mengeksplorasi manfaat gambir. Katekin gambir mempunyai daya hambat terhadap bakteri Streptococcus mutans ${ }^{14}$. Bakteri ini merupakan flora normal rongga mulut dan dapat berubah menjadi patogen apabila kebersihan rongga mulut berkurang. Pembuatan katekin sebagai obat kumur yang didasarkan pada penelitian katekin sebagai antimikroba dapat menghambat sintesis insoluble glucan oleh glucosyltransferase sampai $48,9 \%$ pada konsentrasi $10 \mathrm{mg} / \mathrm{ml}$ dan sampai dengan $32,2 \%$ pada konsentrasi $1,25 \mathrm{mg} / \mathrm{ml}$, sehingga dapat mengurangi pembentukan plak gigi ${ }^{15}$. Penggunaan katekin gambir pada konsentrasi 1-5\% mempunyai aktivitas antibakteri berkisar 20,45-43,24\%. Semakin tinggi konsentrasi, maka semakin besar kemampuan katekin dalam menghambat pertumbuhan bakteri Streptococcus mutans ${ }^{16}$.

\section{METODE}

Penelitian ini merupakan penelitian quasy experimental dengan rancangan penelitian pre-test and post-test with control group design. Penelitian ini dilaksanakan pada bulan Maret - April 2019. Sampel penelitian ini yaitu mahasiswa Fakultas Kedokteran Gigi Universitas Andalas. Perhitungan sampel didapatkan hasil sebanyak 44 orang sampel. Sampel dipilih berdasarkan kriteria inklusi dan eksklusi yang didapatkan melalui penyebaran angket dan pemeriksaan, sampel yang sudah memenuhi kriteria kemudian diminta persetujuannya dengan mengisi informed consent. Sampel dibagi menjadi 2 kelompok, yaitu kelompok perlakuan dan kelompok kontrol. Kelompok perlakuan yaitu kelompok yang menyikat gigi dengan pasta gigi katekin dan kelompok kontrol yaitu kelompok dengan pasta gigi plasebo.

Pasta gigi katekin yang digunakan adalah pasta gigi dengan formularium standar dari Laboratorium Farmasi Unand yang ditambahkan katekin dengan konsentrasi $5 \%$. Sedangkan pasta gigi plasebo yang digunakan adalah pasta gigi dengan formularium standar dari Laboratorium Farmasi Unand. Perhitungan 
indeks plak subjek dengan menggunakan indeks Turesky-Gilmore-Glickman dari Quingley-Hein. Pemeriksaan indeks plak awal (pre-test) dilakukan sebelum subjek menyikat gigi dengan pasta gigi yang telah diberikan. Pemeriksaan indeks plak setelah menyikat gigi (post-test) dilakukan setelah subjek berpuasa selama 4 jam. Data yang didapatkan diuji normalitasnya menggunakan uji normalitas Saphiro Wilk, kemudian dilakukan analisis statistik uji T.

\section{HASIL DAN PEMBAHASAN}

Berdasarkan hasil uji statistik menunjukkan rerata penurunan indeks plak menyikat gigi dengan pasta gigi yang mengandung katekin gambir lebih tinggi dari pada menyikat gigi dengan plasebo. Hasil analisis univariat dilakukan untuk mengetahui rata-rata dan standar deviasi indeks plak sebelum dan sesudah menyikat gigi dengan pasta gigi uji serta selisih keduanya. Hasil tersebut dapat dilihat pada tabel dibawah ini.

Tabel 1. Rerata dan simpangan baku indeks plak sebelum dan sesudah

\begin{tabular}{lccccc}
\hline Kelompok & $\mathbf{n}$ & Perlakuan & Min-Max & Mean & SD \\
\hline Kontrol & 2 & Pre-test & $0.71-2.10$ & 1.25 & 0.39 \\
& 2 & Post-test & $0.32-1.94$ & 0.91 & 0.39 \\
& & Selisih & $0.04-0.55$ & 0.33 & 0.12 \\
Perlakuan & 2 & Pre-test & $0.72-1.46$ & 1.08 & 0.18 \\
& 2 & Post-test & $0.21-0.86$ & 0.45 & 0.16 \\
& & Selisih & $0.42-0.83$ & 0.62 & 0.12 \\
\hline
\end{tabular}

Berdasarkan tabel 1 menunjukkan bahwa rata-rata indeks plak gigi mengalami penurunan setelah menyikat gigi dengan pasta gigi katekin gambir. Hal tersebut terlihat dari tabel 1 bahwa penurunan rerata indeks plak tertinggi pada kelompok perlakuan sebesar $0.62 \pm 0.12$ dan penurunan indeks plak terendah pada kelompok kontrol sebesar $0.33 \pm 0.12$. Hal ini disebabkan karena pasta gigi katekin gambir merupakan senyawa polifenol yang mempunyai aktivitas antibakteri, sehingga dapat menghambat pembentukan plak gigi ${ }^{13}$. Polifenol mampu mencegah adhesi bakteri pembentuk plak gigi ke pelikel dengan cara menghambat aktivitas enzim glucosyltransferase penyebab terjadinya glukan. Ikatan glukan membentuk polisakarida ekstraseluler yang merupakan bagian dari matriks interseluler penyusun plak. Jika glukan tidak terbentuk, maka pembentukan plak menjadi terhambat sehingga terjadi penurunan indeks plak gigi ${ }^{17}$. Hasil penelitian ini sesuai dengan hasil penelitian yang telah dilakukan sebelumnya oleh Aning, didapatkan hasil bahwa berkumur dengan air rebusan gambir dapat menurunkan indeks plak gigi. Penelitian tersebut didapatkan hasil rata-rata indeks plak mengalami penurunan setelah berkumur dengan air rebusan gambir selama 2 menit ${ }^{18}$.

Uji paired sample t-test dilakukan untuk melihat perbedaan rata-rata indeks plak sebelum dan sesudah menyikat gigi pada kelompok kontrol. Hasil uji paired sample t-test dapat dilihat pada tabel berikut: 
ANDALAS DENTAL JOURNAL

Fakultas Kedokteran Gigi Universitas Andalas

Jalan Perintis Kemerdekaan No. 77 Padang, Sumatera Barat

Web: adj.fkg.unand.ac.id Email: adj@dent.unand.ac.id

Tabel 2. Hasil Uji paired sample t-test kelompok kontrol

\begin{tabular}{lcccc}
\hline & $\mathbf{n}$ & Mean & SD & $\boldsymbol{P}$ \\
\hline Pre-test & 22 & 1.25 & 0.39 & $<0.001$ \\
Post-test & 22 & 0.91 & 0.39 & \\
\hline
\end{tabular}

Berdasarkan Tabel 2 menunjukkan adanya perbedaan yang bermakna antara rerata penurunan indeks plak sebelum dan sesudah menyikat gigi pada kelompok kontrol. Hal tersebut terlihat dari Tabel 2 bahwa terdapat perbedaan rerata indeks plak yang bermakna antara sebelum dan sesudah menyikat gigi pada kelompok kontrol karena memiliki nilai $p<0,001 \quad(p<0,05)$. Hal ini dapat disebabkan karena efek mekanis yang dihasilkan dari menyikat gigi dapat melarutkan polisakarida ekstraseluler penyusun plak yaitu ikatan glukan yang berperan penting dalam proses awal pembentukan plak dengan mempermudah adhesi bakteri ke pelikel. Jika glukan tidak terbentuk, maka pembentukan plak akan menjadi terhambat. $\mathrm{Hal}$ ini sesuai dengan penelitian yang menggunakan pasta gigi plasebo sebagai kelompok kontrolnya. Penelitian tersebut didapatkan hasil rata-rata indeks plak mengalami penurunan setelah menyikat gigi dengan pasta gigi plasebo, namun penurunan tidak sebesar kelompok perlakuannya yang menggunakan tumbuhan herbal ${ }^{8}$.

Tabel 3. Hasil Uji paired sample t-test kelompok perlakuan

\begin{tabular}{lcccc}
\hline & $\mathbf{n}$ & Mean & SD & $\boldsymbol{P}$ \\
\hline Pre-test & 22 & 1.08 & 0.18 & $<0.001$ \\
Post-test & 22 & 0.45 & 0.16 & \\
\hline
\end{tabular}

Pada Tabel 3 menunjukkan bahwa terdapat perbedaan rerata indeks plak yang bermakna antara sebelum dan sesudah menyikat gigi pada kelompok perlakuan karena memiliki nilai $p<0,001(p<0,05)$. Uji $T$ independent dilakukan untuk mengetahui perbedaan rerata selisih indeks plak pada kelompok kontrol dan perlakuan. Hasil uji $T$ independent diperoleh nilai $p<0,05$ yang berarti terdapat perbedaan bermakna antara selisih indeks plak kelompok kontrol dan perlakuan.

Tabel 4. Hasil uji $T$ independent kelompok perlakuan dan kontrol

\begin{tabular}{lccc}
\hline Kelompok & $\mathbf{N}$ & Mean \pm SD & $\boldsymbol{P}$ \\
\hline Kontrol & 22 & $0.33 \pm 0.12$ & $<0.001$ \\
Perlakuan & 22 & $0.62 \pm 0.12$ & \\
\hline
\end{tabular}

Berdasarkan Tabel 4, hasil uji $T$ independent menunjukkan bahwa terdapat perbedaan yang signifikan selisih rata-rata penurunan indeks plak antara kelompok kontrol dan perlakuan dengan nilai $p<0,001$. Menyikat gigi dengan pasta gigi yang mengandung katekin gambir lebih baik dalam menurunkan indeks plak dibandingkan dengan menggunakan pasta gigi plasebo.

Senyawa katekin sebagai antibakteri memiliki dua sifat, yaitu mampu menghambat (bakteriostatik) dan membunuh (bakterisida) pertumbuhan bakteri penyebab plak gigi. Katekin gambir mampu 
menghambat pembentukan insoluble glucan dari sukrosa oleh glucosyltransferase yang menyebabkan terhambatnya proses glikosilasi, sehingga proses pembentukan polisakarida ektraseluler oleh bakteri terhambat. Glukan berperan penting dalam proses perlekatan bakteri ke pelikel gigi ${ }^{19}$. Dengan terhambatnya proses ini, maka proses perlekatan bakteri ke pelikel gigi akan terhambat, sehingga mencegah proses kolonisasi awal pada pembentukan plak gigi. Dengan terhambatnya proses kolonisasi awal ini, maka proses selanjutnya yaitu proses kolonisasi sekunder yang ditandai dengan terjadinya koagregasi bakteri-bakteri lain ke bakteri-bakteri pada kolonisasi awal dan proses maturasi plak gigi akan terhambat pula, sehingga pembentukan plak gigi secara keseluruhan akan terhambat ${ }^{20}$.

Senyawa katekin menghambat bakteri dengan cara merusak membran sitoplasma bakteri yang menyebabkan bocornya metabolit penting yang menginaktifkan sistem enzim bakteri. Senyawa katekin melepaskan ion $\mathrm{H}^{+}$yang menyerang gugus hidfrofilik (gugus hidroksi dan fosfat) pada permukaan membran sel. Gugus hidroksi pada molekul ergosterol yang berikatan dengan hydrogen tidak mampu mempertahankan ikatan dan kedudukannya. Membran sel tidak mampu menahan tekanan dalam, akibatnya sitoplasma dalam sel akan menembus keluar ${ }^{21}$.

Kemampuan bakterisidal katekin mampu mendenaturasi protein bakteri dan menurunkan tegangan permukaan sel, karena gugus fenol yang terkandung dalam katekin. Gugus fenol tersebut merupakan senyawa toksik yang mengakibatkan struktur tiga dimensi protein terganggu dan terbuka mejadi struktur acak tanpa adanya kerusakan pada struktur kerangka kovalen. Hal ini mengakibatkan protein berubah sifat, tetapi deret asam amino protein tersebut tetap utuh. Aktivitas biologis ini akan menjadi rusak, sehingga bakteri tidak dapat bertahan hidup ${ }^{18,21}$.

Hasil penelitian ini sesuai dengan penelitian sebelumnya, yang menunjukkan bahwa menyikat gigi dengan pasta gigi katekin gambir $0,1 \%$ dapat berfungsi sebagai antibakteri Streptococcus mutans yang dapat menurunkan indeks plak gigi23.

\section{SIMPULAN}

Dari penelitian yang telah dilakukan dapat ditarik kesimpulan, pasta gigi yang mengandung katekin gambir (Uncaria gambir Roxb) dapat menurunkan indeks plak gigi.

\section{KEPUSTAKAAN}

1. Kementerian Kesehatan Republik Indonesia. Rencana Program Pelayanan Kesehatan Gigi dan Mulut, 2012. Diakses dari http://digilib.poltekkessdepkessby.ac.id/public/POLTEKKESSBY-Books560-Rencanaprogrampe layanankesehatangigi danmulut.PDF pada tanggal 22 Desember 2018.

2. Kementerian Kesehatan Republik Indonesia. Riset Kesehatan Dasar (Riskesdas). 2013. Diakses dari http://www.depkes.go.id/resources/ download/general/Hasil\%20Riskesdas\%202013.pdf pada tanggal 22 Desember 2018.

3. Kementerian Kesehatan Republik Indonesia. Infodatin Situasi Kesehatan Gigi dan Mulut. 2014. Diakes dari http://www.depkes.go.id/download. php?file=download/pusdatin/infodatin/infodatin-gi lut.pdf pada tanggal 20 Desember 2018. 
Fakultas Kedokteran Gigi Universitas Andalas

Jalan Perintis Kemerdekaan No. 77 Padang, Sumatera Barat

Web: adj.fkg.unand.ac.id Email: adj@dent.unand.ac.id

4. Biesbrock, A. R. et al. Oral hygiene regimens, plaque control, and gingival health: A two-month clinical trial with antimicrobial agents. Journal of Clinical Dentistry, 2007; 18(4): 101-105.

5. Figuero, E. et al. Mechanical and chemical plaque control in the simultaneous management of gingivitis and caries: a systematic review. Journal of Clinical Periodontology, 2017; 44: S116-S134. doi: $10.1111 /$ jcpe.12674.

6. Adams, S. E. et al. A randomised clinical study to determine the effect of a toothpaste containing enzymes and proteins on plaque oral microbiome ecology. Scientific Reports, 2017, pp. 1-12. doi: 10.1038/srep43344.

7. Rossi, A. De et al. Antimicrobial Activity of Toothpastes Containing Natural Extracts, Chlorhexidine or Triclosan. Brazilian Dental Journal, 2014; 25(3): 186-190.

8. Listyasari, N. A., Pengaruh Pasta Gigi dengan Kandungan Propolis terhadap Pembentukan Plak Gigi, 2012. Skripsi. Diakses dari http://eprints.undip.ac.id/37645/, pada tanggal 1 Januari 2019.

9. WHO. Guidelines on developping consumer information on proper use of traditional, complementary, and alternative medicine, Zhurnal Eksperimental Teoreticheskoi Fiziki, 2004. Diakses pada http://www.who.int/iris/ handle/10665/42957\%://air/.unimi.it/handle/2434/46025 pada tanggal 5 Januari 2019

10. Lestari, P. Studi Tanaman Khas Sumatera Utara yang Berkhasiat Obat. Jurnal Farmanesia, 2016; 1(1): 11-21.

11. Dhalimi, A., Permasalahan Gambir (Uncaria gambir L.) di Sumatera Barat dan Alternatif Pemecahannya. Prospektif, 2006; 5(1): 46-59.

12. Atman dan Misran. Prospek pengembangan tanaman gambir di Sumatera Barat, Menguak Potensi Teknologi Spesifik Lokasi Guna Mencapai Kesejahteraan Petani. Kristal Multi Media, 2015, pp. 105124.

13. Islamiaty, R. R., et al., Aktivitas farmakologi gambir (Uncaria gambir Roxb). Jurnal Farmaka, 2018; 16: 222-230.

14. Pambayun, R., et al., Sensitivity of Gram-Possitive Bacteria Toward Catechin Extracted from Gambir (Uncaria gambir Roxb). Jurnal Agritech, 2008; 28 (4): 174-179.

15. Lucida, H. Bakhtiar A., Putri. W. A., Formulasi sediaan antiseptik mulut dari katekin gambir. Jurnal Sains Teknologi Farmasi FMIPA Universitas Andalas Padang, 2006; 12(1): 1-7.

16. Amos. Gambir sebagai antibakteri dalam formulasi obat kumur. Jurnal Sains dan Teknologi. 2009; 11(3): 188-192.

17. Gerwin, H., Enhanced (+) Catechin Transglucosylating Activity of Streptococcus mutans GS-5 glukosyltransferase-D due to Fructorase Removal, 2004. Diakses dari http://asmusa. org pada tanggal 2 Januari 2019.

18. Aning, Susilowati., Sumarawati, T., Kajian Lama Kumur Air Rebusan Gambir (Uncaria Gambir) terhadap Pembentukan Plak Gigi. Jurnal Sains Medika, 2012; 4(1): 57-62.

19. Kozai, K., et al., Potential of Gambier as an Inhibitor of Dental Plaque Formation. Dental Journal, 1995; 28: 95-96. 
Fakultas Kedokteran Gigi Universitas Andalas

Jalan Perintis Kemerdekaan No. 77 Padang, Sumatera Barat

Web: adj.fkg.unand.ac.id Email: adj@dent.unand.ac.id

20. Wiria, Florensia. Perbandingan efektivitas berkumur dengan larutan teh hijau seduh konsentrasi $100 \%$ dan $50 \%$ dalam menghambat pembentukan plak gigi secara klinis pada enam permukaan gigi, 2005. Skripsi. Diakses dari http: //lib.ui.ac.id/file?file=digital/125716-R17-PER-21 6\%20Perbandingan\%20efektivitas-HA.pdf pada tanggal 1 April 2019.

21. Rustanti, E., Akyunul, J.A., Ghanaim, F., Uji Aktivitas Antibakteri Senyawa Katekin dari Daun Teh (Cameliasinensis L.var assamica) terhadap Bakteri Micrococcusluteus. Alchemy, 2013; 2(2): 138-149.

22. Dea, H. Daun Sirih sebagai Pasta Gigi Anti Bakteri. Jurnal Persatuan Dokter Gigi Indonesia, 2010. Diakses dari http://www.pdgionline.com/v2/index .php?option=com_content\&task=view\&i $d=594 \& / t$ emid=1, pada tanggal 5 Januari 2019.

23. Bayuarti, Y. D., Kajian Proses Pembuatan Pasta Gigi Gambir sebagai Antibakteri, 2006. Skripsi. Diakses dari https://repository.ipb.ac.id/jspui/b itstream/123456789/3840/4/F06ydb.pdf pada tanggal 13 Februari 2019. 